\title{
COMMUNICATIVE AND PRAGMATIC FUNCTIONS OF LEXICAL BLENDS IN ADVERTISING DISCOURSE
}

\author{
Medvid Olena \\ $\mathrm{PhD}$ in Philology \\ ORCID 0000-003-0723-5753 \\ Sumy State University \\ 2, Rymskoho-Korsakova st, Sumy, 40007, Ukraine \\ o.medvid@gf.sumdu.edu.ua \\ Solomka Alyona \\ Master in Philology \\ Sumy State University \\ 2, Rymskoho-Korsakova st, Sumy, 40007, Ukraine \\ alyona.rozanowa@gmail.com \\ Vashyst Kateryna \\ Lecturer \\ ORCID 0000-0002-2381-1143 \\ Sumy State University \\ 2, Rymskoho-Korsakova st, Sumy, 40007, Ukraine \\ k.vashyst@gf.sumdu.edu.ua
}

The article examines the communicative and pragmatic functions of lexical blends in advertising discourse. It determines that advertising discourse is an area that actively uses lexical blends due to its accuracy, information compression, and simplicity of formation. The concept of advertising, which is defined as a special type of communication, the purpose of which is to have a communicative impact on a potential consumer, has been clarified.

The article also describes the classification of advertising types according to various criteria. The main goal of advertising is defined, that is, influencing both specific individuals and society as a whole, and the main purpose of an advertising text is determined, that is to attract attention and promote sales of goods and services.

The concept of blending as one of the most productive ways of word formation in the English language (the language of analytical structure) has been clarified. The authors determine that blending represents the great potential for giving the word an expressive and evaluative color compared to other word-formation ways. They consider and describe the potential of blends not only in Germanic (English and German), but also in Slavic (Ukrainian) languages, having the different - synthetic structure. Examples of blends in English, German, and Ukrainian advertising discourse are analyzed.

The research studies the communicative and pragmatic functions that reflect both the speaker's attitude to the content of the message and its recipient. The article defines that the communicativeness of the blend is in its ability to establish contact with the message recipient, and the pragmatic aspect is to convince the consumer to buy the advertised product.

This article provides an up-to-date idea of the communicative and pragmatic functions of blends in English, German and Ukrainian advertising discourse, as these lexical units strive for expressiveness, evaluation, brevity, and help to attract the attention of the reader or listener.

Keywords: blending, lexical blend, advertising discourse, communicative influence, communicative and pragmatic functions, informational message, language means.

(C) Medvid O., Solomka A., Vashyst K., 2020 


\section{Introduction}

The 21 st century is the time of active application of the language economy principle, as a result of which the processes of reduction, abbreviation, and blending have become unprecedented. Advertising discourse is an area that actively uses blends as a stylistically marked, expressive, and at the same time, laconic lexical means. Due to their accuracy, information compression, and ease of formation, blends are widely used in advertising slogans and messages, as names of products or organizations and companies, serving to attract consumers' attention, create an image, and so on.

Such researchers as L. Lipka (1981), M. Turner \& G. Fauconnier (1998), J. Algeo (2000), T. R Timoshenko (2001), S. Kemmer (2003), C. Friedrich (2008), O. V. Kosovych (2014), K. M. Vashyst (2020) and many others studied blending as a productive way of wordformation. The analysis of advertising discourse is presented in the works by F. Jefkins (1994), K. L. Bove (1995), R. Lakoff (2000), I. M. Gordon (2003), M. D. Pazukha (2006), Ye. N. Serdobintseva (2010), G. M Kostenko (2014), V. V. Samarina (2015), O. S. Tielietov (2015) and others. However, the issue of the functional potential of blends in Germanic and Slavic languages within the advertising discourse is not sufficiently covered today, that determines the relevance of this article.

The object of the research is blending as a productive way of word-formation in modern linguistics. The subject of the study is the communicative-pragmatic function of blends in English-language, German-language, and Ukrainian-language advertising messages.

The goal of the research is to analyze the features of the communicative-pragmatic function of blends in English, German and Ukrainian advertising. It is necessary to perform a number of tasks: study the features of the advertising text; define blending as a productive way of word formation; describe the types of blends in English, German and Ukrainian advertising; analyze the communicative-pragmatic function of blends in advertising discourse.

To achieve the goal and the tasks of the research, such general and special methods were used: information retrieval method - for the selection of empirical material and systemizing basic knowledge; generalization method - to highlight the most significant theoretical issues; contextual and functional methods - to actualize the pragmalinguistic significance of linguistic units under study - lexical blends, as well as the method of structural-semantic and component analysis - to determine the ways of blends formation and their main structural elements in Germanic and Slavic languages.

\section{Theoretical issues}

Advertising is a communicative phenomenon of social and linguistic-cultural significance. Advertising is an effective special means of communication influence on the recipient; an information message, the purpose of which is the communicative impact on the potential consumer (Gordon, 2003). Its strategic task is to promote, in various ways and by all available means, something or someone in order to create demand for a product, service, person, event, idea, etc.

A characteristic feature of advertising is that it is always performed at the request of a particular social institution. There are three main types of advertising, depending on the type of such institutions:

1) commercial (aimed at the promotion and sale of goods and services; generated by commercial organizations that are part of various economic institutions);

2) political (promotes political parties and their members, create the image of state structures or organizations; ordered by regulatory institutions);

3) social (draws attention to some urgent problems of society, aimed at changing the patterns of social behavior; ordered by regulatory and economic institutions) (Bove, 1995).

Some scientists (F. Jefkins, 1994) suggest dividing advertising according to the following criteria: object, subject, means of implementation and purpose of advertising. Advertising is also classified depending on the method of its influence: 1) rational advertising, i.e one, that appeals to the mind of a potential buyer, and 2) emotional or associative, which influences through the association of ideas, by reproducing the situation and mode of 
expression; advertising that has short-term goals and is designed for medium-term impact on the consumer (Lakoff, 2000).

Advertising aims to: - attract the attention of potential buyers; - provide the buyer with specific benefits from the purchase of goods or services; - provide the buyer with opportunities for additional study of the product; - form a certain level of knowledge about the goods or services; - create a favorable image of the manufacturer or seller, as well as a trademark or production brand for consumers and business partners; - cause the need for this type of goods and services; - encourage a potential buyer to purchase this particular product from this particular company, and not from competitors; - remind the consumer about the company and its products (Kostenko, 2014).

As we can see, among the goals pursued by advertising, there are clearly defined goals that involve influencing the consumer, inspiring him / her with certain thoughts, desires, and actions. Advertising in the modern world has a significant impact on both individuals and society as a whole. The effect of advertising is realized by influencing human psychology. And as a result, it actively participates in the formation of psychological attitudes of an individual, the systems of his / her environmental assessments and self-esteem, the nature of reactions to various stimuli, the creation of specific psychological climate, etc.; and in this multi-purpose process, perhaps, the most important position is occupied by modern language means, which are implemented through the text of the advertising message for various purposes (Tielietov, 2015).

Advertising text contains information, mostly presented in a concise, artistically expressed form with a characteristic emotional color, and brings the most important facts and information about goods and services to the consciousness and attention of potential buyers. Thus, advertising message, on the one hand, brings to consumers the information necessary for the purchase and use of goods, and on the other hand, combining its information with persuasiveness and methods of suggestion, has an emotional and psychological impact on a person (Pazukha, 2006). The purpose of the advertising text is to attract the person's attention and motivate him / her to act - to buy a product or service, as well as to assure a person that the product is not only necessary and attractive but also profitable. That is why advertising specialists use a variety of psychological and linguistic techniques. Advertising texts should be bright, simple, concise, accessible, expressive, and informative. In order to achieve this goal, the authors of advertising texts use a number of languages means: lexical, graphic, stylistic, phonetic, syntactic, morphological, and word-forming ones.

The communicative-pragmatic function is one of the main functions of the advertising message. T.V. Melkumova (2016) observes the communicative-pragmatic function in the fact that the speaker, forming his communicative strategy, plans in advance and implements in the process of speech specific techniques aimed at achieving the communicative, and pragmatic goals, in particular, manipulation of the recipient of the advertising message.

The function of lexical blends in the implementation of the communicative-pragmatic function is significant, because these lexical units are extremely "fashioned", such that "keep up with the times". For example, blends can reflect the general features of today's globalized world, where one of the most important issues is saving time.

O. V. Kosovych (2014) provides such a definition of blending: it is an independent way of word-formation, which generates a kind of units - contaminations (blends), which have both universal and linguo-creative features. According to the researcher, blend words are a type of vocabulary that can be created by truncation. Thus, blend is a new way of word -formation in which a part of one word merges with a part of another word or with a whole word to form a single lexical innovation.

In English, there are four types of blends. Being based on the blend words classifications by J. Algeo (2000) and T. R. Timoshenko (2001), we can single out the following most popular subgroups:

1. The most frequent type of blending is a combination of two truncated stems with the imposition of a phoneme or groups of phonemes on the joint point (usually such formations are called "mergers"). This type of bland is created by the formula $\mathrm{A}(=\mathrm{abc})+\mathrm{B}(=\mathrm{dbe})-\mathrm{C}$ 
$(=$ abe $)$. For example: globflation $=$ glob $(a l)+($ in $)$ flation - "the level of inflation in the context of globalization", or absotively $=$ abso $($ lutely $)+(p)$ ositively - "very positive";

2. The combination of the initial fragment of the source word with the final fragment of the second one without interword overlay. This type can be represented by the formula A (= $\mathrm{ab})+\mathrm{B}(=\mathrm{cd}) \rightarrow \mathrm{C}(=\mathrm{ad})$. For example: annoyware = annoy $($ ing $)+($ soft $)$ ware - "software that is annoying"; babelicious $=$ bab $(y)+(d)$ elicious - "attractive woman";

3. The combination of the source word's full stem with the truncated stem of another word, with or without phonemes imposition. This type can be represented by three formulas:

a) the source word, the stem of which is preserved, is the first word

1. $\mathrm{A}(=\mathrm{ab})+\mathrm{B}(=\mathrm{bcd})->\mathrm{C}(=\mathrm{abc})$, where the imposition of phonemes is obligatory: lametarded = lame $+(r)$ etarded - "backward";

2. $\mathrm{A}(=\mathrm{ab})+\mathrm{B}(=\mathrm{cd})-, \mathrm{C}(=\mathrm{abd})$ without phonemes overlapping: joygasm $=$ joy $+($ or $)$ gasm - great joy;

b) the source word, which is stored in the telescopic lexical innovation, is the second word, and it is formed according to the formula $\mathrm{A}(=\mathrm{acb})+\mathrm{B}(=\mathrm{cd})-$ > $\mathrm{C}(=$ acd): mathemagician $=$ mathema $($ tician $)+$ magician - "a person, which is very good in mathematics"; automagically = automa (tically) + magically - "an observer has no understanding of the mechanism of action, and it seems to him almost magical";

4. The combination of two complete stems with interword overlay (haplology), which is formed by the formula $\mathrm{A}(=\mathrm{ab})+\mathrm{B}(=\mathrm{bc})->\mathrm{C}(=\mathrm{abc})$ : boughetto = bough + ghetto - " $\mathrm{a}$ person who wants to look like a representative of the upper class, but actually belongs to the lower one".

Blending, as one of the ways of word-formation in the English language, the language of world communication, represents the great potential for giving the word stylistic connotation, expressive and evaluative color, comparing to all other ways of word- formation.

\section{Discussion and Results}

Due to the simplicity and ease of their formation, blends are popular in advertising discourse and used to denote various phenomena, for example: the wordblend advertorial means "advertisement written in the form and style of an editorial"; infomercial is "a television commercial that resembles an information announcement". As you can see, the resulting blends are shorter and semantically more capacious than full phrases. At the same time, they are informative because they contain the semantic meanings of both shortened words, which form the stem of the blend.

A number of advertising blends are trade-related. They reflect the current trend of marketing that is the increasing use of information technology, media resources and even Internet to advertise products. For example, a computer game on a website that incorporates advertising content and a vivid image is called advergame; advertecture - a collective name for advertisements painted on the walls of buildings. Advertising agencies have started writing novels - fictomercials, which are permeated with advertising messages, and each line is designed to promote their products.

A significant part of blend corpora within English-language advertising discourse contains proper names (onyms), including ergonomics and the names of certain goods and services. An example is a well-known company Nestle, whose product names are actively used in advertising texts, and not only in English: both the element of the manufacturer's name and the of the product's name:

Nescafé $=$ Nestle + café, Nespresso $=$ Nestle + expresso, Nesquik $=$ Nestle + quick, Nestea $=$ Nestle + tea .

One more example, a restaurant can realize the effect of the economy by using advertisements with blends: brunch = breakfast + lunch - "a meal that is later than breakfast, but earlier than lunch"; brinner = breakfast + dinner - "eating meals, associated with breakfast, but for dinner". The combination of the meals is very typical to the modern way of life. This is reflected in blends, thus creating a new reality that is fresh and close to the recipients of advertising. The word frappuccino (frappe + cappuccino) performs such a 
function - although the recipient of the advertising text is already familiar with "frappe" and "cappuccino" drinks, their combination in the unusual "frappuccino" will be of interest, even if it is obvious that there is nothing fundamentally new in such "new product". The name of the product, which has the form of a blend, in this case, has such a powerful, pragmatic significance that it can persuade a consumer to buy the product, even if it is of no need.

Now, let's consider blends in German. In German, there are two main structural types: phonetic and graphic blending.

Phonetic blending is divided into three subtypes: fusion telescopy (overlay of stems A and B), sequential telescopy (no overlap of stems A and B), and integrated telescopy (inclusion of stem B in the structure of stem A).

Fusion telescopy is implemented in the following models (Friedrich, 2008):

1. without reduction of stems A and B (the final segment of stem A coincides with the initial segment of stem B): elefantastisch (Elefant + fantastisch), Frostsee (Frost + Ostsee);

2. with the reduction of stem A: AbentEuro (Abenteuer + Euro), akadämlich (academic + dämlich); Verkehr)

3. with the reduction of stem B: Bankfurt (Bank + Frankfurt), Fairkehr (fair + + billig).

4. with the reduction of both stems A and B: Birnane (Birne + Banane), brillig (Brille

In the case of sequential telescopy, the stems A and B do not overlap, but follow each other sequentially. There are also three models:

1. with the reduction of stem A: augenKlick (Augenblick + Klick), denglisch (deutsch + englisch);

2. with the reduction of stem B: bierologisch (Bier + biologisch), centsationell (Cent + sensationell);

3. with reduction of both stems A and B: Familotel (Familie + Hotel), Fanamik (Fahrspaß + Dynamik).

Integrated telescopy, in contrast to fusion and sequential types, is much less common and involves the inclusion of stem B into stem A: BiRadlon (Biathlon + Rad), Psychartrie (Psychiatrie + art [Kunst]) (Fridrich, 2008).

L. Lipka's (1981) study on the functioning of blends proves that blending is also a productive way of word formation in the German language. The scientist divides the blends into the following thematic groups: food (Hellikatesse (hell + Delikatesse) - "a poster of Paulaner, which advertises light beer, which they consider a delicacy"); leisure and tourism (Urlaubär (Urlaub + bär) - "a water toy in the shape of a bear, which is often taken on vacations"); culture and art (Liebesmü'sique (Liebesmühe + musique) - "the name of the program of one vocal ensemble, which sings about love torments in its songs"); sports (Beckingham Palast - Beckham + Buckingham Palace) - "the name of the house of Beckham and his wife, reminiscent of Buckingham Palace; science (Schiege (Schaf + Ziege) - "a hybrid of sheep and goats"; society (Ökolozismus (Ökologie + Katholizismus) - "an entity that combines ecology and Catholicism"); technology (BrakeMatic (brake + automatic)"automatic brake device"), etc.

As for the mass media discourse, S. Kemmer (2003) found the presence of blends in various newspapers and magazines: ones about politics, youth, women, business, cars, travel. Some innovative mass media include blends in their names (AirLEBNISBLATT (Airport + Erlebnisblatt) - "an advertisement for the Airport disco, covering everything that happens there as bright events"; Vorsicht StuVe! (Vorsicht Stufe + StuVe!) (student meeting) is "the name of a newspaper published by a student meeting with a hint that it should not be underestimated". Blends are often included in the headlines on magazine covers and captions to pictures in order to attract readers, arouse their interest and make them buy newspapers and magazines: AbentEuro (Abenteuer + Euro) - "the title of an article whose author has conflicting feelings about the euro introduction"; NACHTDENKEN (Nacht + nachdenken) (night reflection) - "a caption under the photo of Professor J. Searle in the university library, where he meditates at night alone". 
The scientists emphasize that the widespread use of blends in advertising is due to the fact that companies and manufacturers want their products to look original and attractive for customers. Such blends evoke associations with aesthetics, creativity and innovation and have a strong emotional impact on readers (O. Tielietov, 2015, K. Vashyst, 2020). The authors find the blends in advertising often to have a positive connotation and evoke pleasant associations, negatively colored blends are quite rare: (pfanntastisch (frying pan + fantastic) - advertising of excellent frying pans); (Sixt kämpft gegen den Massenteurismus - Sixt (a company that sells and rents cars) is struggling with a massive rise in prices). The author notes that blends in advertising often perform appellate and phatic functions: VERABSCHWEDET EUCH (Verabredet euch + Schweden - announcement of the IKEA opening in one of the lands of Germany, where Germans are invited to come shopping in a Swedish store); Kaufwiedersehen! - Goodbye! Thank you for purchasing!

The analysis of the corpora under research proves that the use of blends is popular now not only in languages with analytical structure, this trend towards language economy and increasing semantic capacity of lexical units is becoming popular also in Slavic languages (which grammatical structure is synthetic), although there are much less examples of blends in the vocabulary of these languages. The search for empirical material for analysis led us to the streets of our native town, where once again we came across the dynamism of advertising discourse, which is full of innovation samples, Ukrainian lexical blends including.

For example, Мьяс'єм (Myasyem - “meat eating”) is a meat shop in Sumy (Northeastern Ukraine). Taking into account compounding rules violation, it is a typical blend, both in terms of structural elements combination and in terms of a combination of languages that are widely used within the territory of Northeastern Ukraine (Ukrainian and Russian). This is an example of not only pragma-linguistic, but also socio-linguistic significance. As a result, we have an original play of words, which in addition performs a commercial function, attracting the attention of a buyer.

СервелатIK (ServelatIK - “cervelat and the company") is a known butcher shop in Sumy. As you know, cervelat is a kind of high-grade delicious smoked sausages made of veal, pork or rabbit, very popular in Soviet times, and a large number of today's citizens of Ukraine remember this brand. The blend creates positive impression of the company that produces highquality products. Thus, the name of the company becomes a well-known brand, and, performing the pragma-linguistic function of influencing the recipient, it also implements the marketing goals of the company.

Pемвзуття (Remvzuttya - "shoe repair") is a shoe repair factory. This example is not new in the lexicon of Ukrainians, but is interesting in terms of how in languages (in this case in word-formation) there are no precise boundaries: considering that the word ремонт (remont - "repair") is of French origin (This word appeared to us in Peter's time (18th century) in a very special meaning: "replacement of old horses by young ones in the army". Later, this word got the meaning "reconstruction", "adjustment", in the broadest sense of the word "repair of premises, buildings, and mechanisms"). Element -ont is a suffix, and the lexical unit rem-vzuttya should be considered a complex word, uniting two word-roots, but the long life of the word remont combined it with the Ukrainian language so much that even Ukrainian linguists consider remont to be an integral root unit having no suffix (at least of Ukrainian origin). Therefore, remvzuttya can be refered to the initial transitional moments in the processes of Ukrainian-language word-formation, from classical rules to the so-called telescopy or blending. This example implements the effect of saving and is understandable to an average Ukrainian due to the long period of use.

The next example refers to blends that use elements of foreign words, that is very typical for such lexical units. ПрезиДент (PreziDent) is a dental clinic in the town, its name is a combination of foreign words (of Latin origin) president and dentist, which are also used in the Ukrainian language; and non-standard structural merging of these words creates innovative semantics of a blending unit that attracts attention. In addition, the word president means "the head of the country, the first person in the country". Therefore, this component is appropriate; 
it forms the recipient's opinion about the superiority and professionalism of the doctors of this dental clinic.

Nowadays, blends that are formed as a combination of parts of words from different European languages have become more common (enterprising Ukrainians, returning from Europe, open their shops with odd names in Motherland). BoNitka ("yarn shop") is a combination of the Spanish word bonita, which means "beautiful", and the Russian word nitka, which means "thread", which is transliterated in Latin to maintain a single form and melodiousness, that also affects the positive perception of the overall image of the shop.

The next example is formed in a similar way: BEERloga is a well-known beer pub in our town, the name of which is a combination of the English word beer and transliteration of the old Russian word berloga, which means "den" (but initially the root ber- is taken from the German language, which means "bear", only -log- is taken from Russian, that is, "den", "lair": "bear's den"). Therefore BEERloga hints that you may stay at this place to "hide" and "relax".

\section{Conclusions}

Blending is a well-known phenomenon of English word-formation, which has long been spread to all European (Romano-Germanic) languages, including German, and is now becoming a popular phenomenon among Slavic languages, including Ukrainian, as it was shown by the analysis of the empirical material. Mass media, or rather advertising, discourse is the main source of lexical blends, because it tends to expressiveness, evaluability, and brevity of information, which helps to attract the attention of a reader or listener, thereby implementing the communicative-pragmatic function. The communicativeness of a lexical blend is in its ability to establish contact with the recipient through its expressiveness, its modernity, and its ability to reflect such things that other language means cannot do. The pragmatic aspect of using such units in an advertising text is that the speaker, creating his communication strategy, plans in advance and implements in the process of speech certain techniques aimed at achieving the communicative goal - to convince the recipient to buy the advertised product. Prospects for further research of this paradigm are interesting within comparative analysis of blends functioning in different discourses of different European languages.

\section{REFERENCES}

Algeo, 2000 - Algeo J. (2000). Blends, a Structural and Systemic View. American Speech.No. 1/2. Vol. 52. p.p. 47-64

Bove, 1995 - Bove K. L., Arens U. F. (1995). Sovremennaia reklama. Tvorchestvo v sostavlenii reklamnykh tekstov [Modern advertising. Creativity in composing advertising texts]. Toliatty: Dovhan [in Russian]

Friedrich, 2008 - Friedrich C. (2008). Kontamination - Zur Form und Funktion eines Wortbildungstyps im Deutschen. Inaugural-Dissertation in der Philosophischen Fakultät und Fachbereich Theologie der Friedrich- Alexander-Universität Erlangen-Nürnberg. Nürnberg

Gordon,2003 - Gordon I. M. (2003) Advertising or obligation [Reklama abo zoboviazannia]. Kyiv: Prosvita [in Ukrainian]

Jefkins, 1994 - Jefkins F. (1994). Advertising. London: Pitman

Kemmer, 2003 - Kemmer S. (2003). Schemas and lexical blends. Amsterdam Studies in the theory and History of Linguistic Science. Amsterdam; Philadelphia; J. Benjamins Pub. Co. Series 4. p.p. 69-98

Kosovych, 2014 - Kosovych O. V. (2014). Kontaminatsiia u dzerkali neonominatsii. Linhvokreatyvni mozhlyvosti [Contamination in the mirror of neonomination. Linguo-creative possibilities]. Problemy semantyky slova, rechennia ta tekstu [Problems of word, sentence and text semantics]. 32. pp. 96-104 [in Ukrainian]

Kostenko, 2014 - Kostenko H. M. (2014). Prahmatychna reprezentatsiia reklamnykh tekstiv [Pragmatic representation of advertising texts]. Tyzhden nauk [Week of Science]. 4. pp. 31-32 [in Ukrainian] 
Lakoff, 1982 - Lakoff R. (1982). Persuasive Discourse and Ordinary Conversation, with Examples from Advertising. In D. Tannen (Ed.) Analyzing Discourse: Text and Talk. Washington DC: Georgetown University Press. p.p. 25-42

Lipka,1981 - Lipka L. (1981). Zur Lexikalisierung im Deutschen und Englischen. In: Lipka, Leonhard (ed.) : Wortbildung. Wege der Forschung. Darmstadt: Wissenschaftliche Buchgesellschaft. Vol. 564. pp. 119-132

Melkumova, 2016 - Melkumova T. V. (2016). Stan doslidzhennia komunikatyvnoprahmatychnykh funktsii movnykh odynyts [The state of research of communicative-pragmatic functions of language units]. Filolohichni studii: Naukovy visnyk Kryvoriz'koho derzhavnoho pedagogichnoho universytetu [Philological Studies: Scientific Bulletin of Kryvyi Rih State Pedagogical University]. $\quad$ p.p. 63-72. Available from:https://journal.kdpu.edu.ua/filstd/article/download/167/159/ [in Ukrainian]

Pazukha,2006 - Pazukha M. D. (2006). Reklama u pidpryiemnytskii diialnosti [Advertising in business]. Kyiv: Tsentr navchalnoi literatury [in Ukrainian]

Tielietov, 2015 - Tielietov $O$. S. (2015). Osoblyvosti movlennievoho vplyvu v reklamnykh tekstakh [Features of speech influence in advertising texts]. Marketynh i menedzhment innovatsii [Marketing and Menegment of innovations]. 4. pp. 4958 [in Ukrainian]

Tielietov, 2015 - Tielietov O.S. (2015). Reklamnyi menedzhment [Advertising management]. Sumy: Universytetska knyha [in Ukrainian]

Timoshenko, 2001 - Timoshenko T.R. (2001). Teleskopiya v slovoobrazovatel'noisisteme sovremennoho angliiskoho yazyka [Telescoping in the word-formation system of modern English]. Kyiv [in Ukrainian]

Turner, 1998 - Turner M., Fauconnier G. (1998). Conceptual Integration Networks. Cognitive Science. 22(2). p.p. 133-187

Samarina, 2015 - Samarina V. V., Samarin V. V. (2015). Verbalizatsiia komunikatyvnoi stratehii samoprezentatsii vidomych osobystostei $u$ Twitter [Verbalization of communicative strategy of self-presentation of famous personalities on Twitter]. Naukovi zapysky natsionalnoho universytetu "Ostroz'ka Akademia". Seria: Filologichna [Scientific notes of the National University "Ostroh Academy". Series: Philological]. 55. p.p. 231-233 [in Ukrainian]

Serdobintseva, 2010 - Serdobintseva E.N. (2010). Struktura i yazyk reklamnykh tekstov [The structure and language of advertising texts]. Moscow: Flinta: Nauka [in Russian]

Vashyst, 2020 - Vashyst K. M. (2020). Perekladatski deviatsii blendynhovyk verbalnykh odynyts' anglomovnykh reklamnykh povidomlen' [Translation deviations of blending verbal units of English advertising messages]. Vcheni zapysky Tavriiskoho natsionalnoho universytetu imeni V. I. Vernads'koho. "Filologiia. Sotsialni komunikatsii." [Scientific notes of Tavriya National University named after V. I. Vernadsky. Series "Philology. Social communications "]. 31 (70). No. 2. p.p. 42-49 [in Ukrainian]

Received: 22 July, 2020 